\title{
ZHODNOTENIE ĎALŠEJ ETAPY REFORMY VEREJNEJ SPRÁVY V SLOVENSKEJ REPUBLIKE
}

EVALUATION OF THE NEXT STAGE OF PUBLIC ADMINISTRATION REFORM IN THE SLOVAK REPUBLIC

\author{
Ing. MiLena MAJOROŠOVÁ \\ MGR. IVANA KOVÁCSOVÁ \\ Katedra verejnej správy $\mid$ Department of public administration \\ Vysoká škola ekonómie a manažmentu verejnej správy School of Economics and Management in Public \\ $v$ Bratislave Administration in Bratislava \\ Furdekova 16, 85104 Bratislava, Slovak Republic \\ E-mail: milena.majorosova@vsemvs.sk,ivana.kovacsova@vsemvs.sk
}

\begin{abstract}
Anotácia
Turbulencia súčasného celospoločenského prostredia si vyžaduje neustálu realizáciu reforiem verejnej správy. V̌̌etky podstatné zmeny spoločenského prostredia vyvolávajú potrebu zmien riadiacich štruktúr. Po prehodnoteni poslednej etapy reformy verejnej správy, ktorá bola realizovaná v rokoch 1999-2005 vznikla potreba demokratizácie, debyrokratizácie a zefektivnenia výkonu správy veci verejných. Zistili sa nedostatky $v$ troch hlavných oblastiach: špecializovaná štátna správa je neprehladná, neefektivina, nedostupná a prebyrokratizovaná, nedosiahli sa pozitívne efekty $z$ decentralizácie ( $v$ dôsledku vysokej fragmentácie sídelnej štruktúry) a nie je jednoznačne stanovená zodpovednost' za výkon niektorých kompetencii medzi štátnou správou a samosprávou. Tieto problémy chce vláda riešit' prijatím programu ESO, ktorý približuje tento príspevok.
\end{abstract}

\section{Klúčová slová}

verejná správa, reforma, stratégia, ESO - Efektívna, Spol’ahlivá a Otvorená štátna správa

\section{Annotation}

The turbulence of the current overall social environment requires continuous realization of public administration reform. Any material changes to the social environment creating a need for changes in management structures. After reviewing the final stage of public administration reform, which was implemented in the years 1999-2005 created the need for democratization, de-bureaucratisation and streamlining exercise governance. There were deficiencies in three main areas: a specialized government is unclear, ineffective, unavailable, and over-bureaucratic, there have been positive effects of decentralization (due to the high fragmentation of the settlement structure) and is not clearly defined responsibilities for the performance of certain powers between the state and local governments. This government wants to solve problems by adopting ESO program, which approximates this post.

Key words

public administration, reform, strategy, ESO - effective, reliable and open state administration

JEL classification: $H 830$

\section{Úvod}

Svet prechádza v súčasnosti mnohými spoločensko-ekonomickými zmenami, ktoré vplývajú aj na fungovanie verejnej správy. Zmeny, neistota a dynamika procesov sa odrážajú v nevyhnutnosti 
realizácie reforiem. Pre odstránenie neefektívneho, nevýkonného hospodárenia, v ktorom sa plytvá zdrojmi, odvádza sa nekvalitná práca, je nevyhnutné modernizovat' verejnú správu. „Obsahom modernizácie verejnej správy je taká zmena, ktorá vedie k podstatnej kvalitatívnej premene vo fungovaní verejnej správy, $\mathrm{k}$ zefektívneniu jeho fungovania, $\mathrm{k}$ vyššiemu výkonu a rastu kvality práce tak, aby boli na kvalitatívne vyššej úrovni uspokojené oprávnené požiadavky občanov (v zmysle kritéria verejného záujmu), ktoré občania kladú na výkon verejnej správy (Ochrana, Puček, 2011).

Ciel'om príspevku je zhodnotit' priebeh tretej etapy reformy verejnej správy na Slovensku zo zameraním na súčasnú najzásadnejšiu reformu štátnej správy pod názvom ESO.

\section{Reforma verejnej správy}

Reforma verejnej správy je $\mathrm{v}$ ostatných desat'ročiach fenoménom súčasného vývoja väčšiny európskych štátov. Jej intenzita sa zdôvodňuje nasledovne (Stratégia reformy verejnej správy v Slovenskej republike):

- požiadavkou zvýšenej výkonnosti samotnej verejnej správy, a vytvorenia inštitucionálneho systému schopného zabezpečit' správu vecí verejných čo najracionálnejšie,

- potrebou zvýšenia ekonomickej výkonnosti krajiny a jej nižších územných celkov - regiónov a obcí,

- nevyhnutnost'ou reformy fungovania administratívneho štátu,

- tendenciami vstupu do zjednocujúceho sa ekonomického a bezpečnostného systému Európy.

V počiatočnej fáze tranformačného procesu nebola reforma verejnej správy $\mathrm{v}$ krajinách strednej a východnej Európy chápaná ako jeden z jej rozhodujúcich predpokladov. V prvej fáze sa uskutonili iba nevyhnutné, nesystémové zmeny. Zásadnejšie zmena si vyžadovala uskutočnit' systémovú reformu, ktorá sa dotkla všetkých jej prvkov (Combes, Verhijen, 1997):

- územného členenia

- inštitucionálneho systému a

- spôsobu fungovania.

Rovnako ako vo vyspelých štátoch aj na Slovensku sa začal v súvislosti s tranformáciou spoločenskoekonomického systému proces zmien vo verejnej správe. Reforma verejnej správy bola rozdelená do troch základných etáp. V priebehu rokov 1990 - 1991 došlo k vytvoreniu reálnej obecnej samosprávy a zrušeniu krajských národných výborov. Druhá etapa sa uskutočnila v roku 1995 - 1996 a súvisela s reformou územnej štátnej správy. Zásadnú zmenu celého systému priniesla tretia etapa reformy, ktorá bola ovplyvnená charakterom a dynamikou zmien v systéme verejnej správy všetkých krajín strednej a východnej Európy. V rámci tretej etapy reformy sa uplatnili trendy, ktoré poznačili reformné procesy vo verejnej správe v Európe (Nižňanský, 2005):

- zmeny v rozsahu a štruktúre verejného sektora, ako aj v metódach jeho riadenia

- pochopenie verejnej správy ako služby občanovi t.j. ústup o jednoznačného chápania verejnej správy ako mocenského nástroja, najmä v oblastiach, ktoré sú regulované právnymi normami,

- dekoncentrácia štátnej správy,

- decentralizácia verejnej správy s podporou samosprávy,

- fiškálna decentralizácia,

- spolupráca verejného a súkromného sektora,

- uplatňovanie nových metód riadenia vo verejnej správe,

- rast kvalifikácie zamestnancov,

- informatizácia verejnej správy a i.

\subsection{Tretia etapa reformy verejnej správy na Slovensku}

Programové vyhlásenie vlády vymedzilo smerovanie tretej etapy reformy verejnej správy. Vláda sa $\mathrm{v}$ ňom zaviazala:

- upevnit' demokratický právny štát,

- modernizovat' fungovanie štátu, 
- decentralizovat' kompetencie z orgánov štátnej správy na územnú samosprávu,

- decenralizovat' verejné financie,

- ratifikovat' Európsku chartu miestnej samosprávy.

V roku 1999 bola prijatá Stratégia reformy verejnej správy v SR, ktorá vychádzala z východiskovej situácie v usporiadaní verejnej správy a bola dôsledkom nesystémových zmien uskutočňovaných po roku 1990. Túto situáciu možeme charakterizovat’ nasledovne (Hamalová, 2008):

- vysoká miera koncentrácie správy verejných vecí na úrovni centra,

- neukončený model územnej verejnej správy, chýbajúci článok regionálnej samosprávy, ktorý by podporoval uplatňovanie decentralizovaného riadenia verejných vecí,

- nevyhovujúce územno-správne usporiadanie krajiny, ktoré nerešpektovalo pri svojmu vzniku hranice prirodzených územných celkov,

- rezortné, územne nekoordinované riadenie verejných vecí,

- neprehl'adné a málo stimulujúce financovanie verejného sektora,

- tažkopádne, prebyrokratizované a málo výkonné inštitúcie verejnej správy,

- nedostatočná kontrola kvality práce a finančných tokov vo verejnej správe,

- zanedbaný systém permanentného vzdelávania zamestnancov verejnej správy,

- nízka miera decentralizácie kompetencii, od r. 1991 tento proces prakticky nepokračoval.

V dôsledku premeny spoločensko-ekonomických vzt’ahov na Slovensku a celoeurópskych trendov zmien $\mathrm{v}$ národných systémoch verejnej správy musela mat' pokračujúca reforma systémový a komplexný charakter. Reformu nie je možné spájat' len so zmenami územného usporiadania inštitúcií verejnej správy, ale aj so zmenou ich pôsobností, metód riadenia, kvality riadiaceho aparátu, presunom pôsobností a zodpovedností z centrálnej úrovne na územné články, zmenami v systéme tvorby príjmov a výdavkov verejných rozpočtov a i. Súčast'ou tretej etapy reformy verejnej správy bola aj reforma územnej štátnej správy. Reforma územnej štátnej správy mala zohl'adňovat' nasledovné štandardné európske princípy jej usporiadania:

- princíp transparentnosti

- princíp dvojstupňovosti

- princíp subsidiarity

- princíp dostupnosti

- princíp efektívnosti.

V dôsledku pripravovanej decentralizácie, kedy sa mala značná čast' kompetencií presunút' zo štátnej správy na samosprávu, bolo nevyhnutné prispôsobit' týmto zmenám aj organizačnú štruktúru miestnej štátnej správy. Koncepcia pôvodne počítala so zrušením okresných úradov a $s$ návratom špecializovanej štátnej správy. Na základe verejnej diskusie boli na rokovanie vlády predložené dve alternatívy usporiadania územnej štátnej správy:

- zachovanie integrovanej územnej štátnej správy, zníženie počtu krajov z 8 na 4 , zníženie počtu plnohodnotných okresných úradov zo 79 na 44 a ponechanie 35 okresných úradov so zúženými kompetenciami, zachovanie jestvujúcej siete špecializovanej štátnej správy;

- zrušenie integrovaných úradov územnej štátnej správy, rozšírenie siete špecializovaných úradov a zmena postavenia krajských úradov.

Prednost'ou druhej alternatívy bola možnost' vytvorenia symetrického modelu územnej verejnej správy. Zmena, ktorá sa uskutočnila k 1.1.2004, bola najvýznamnejšou zmenou po dokončení procesu decentralizácie. Bola zrušená územná štátna správa so všeobecnou pôsobnost’ou pôsobiaca na úrovni krajov. Boli zrušené okresné úrady, ako správne jednotky. Územná štátna správa má odvtedy len špecializovaný charakter, čo znamená, že sústava orgánov (úradov) prislúcha ministerstvu, a to vecne, metodicky, finančne a personálne (Žárska a kol.). Z toho vyplýva, že ministerstvá a iné ústredné orgány štátnej správy riadia vytvorenú siet' územných orgánov podla charakteru činností. Sústavu územných orgánov štátnej správy vykonávajú krajské a obvodné úrady štátnej správy. Počet obvodných úradov pre jednotlivé oblasti výkonu štátnej správy je rozdielny. 


\section{Obr. 1: Štruktúra verejnej správy $k$ 31.12.2012}

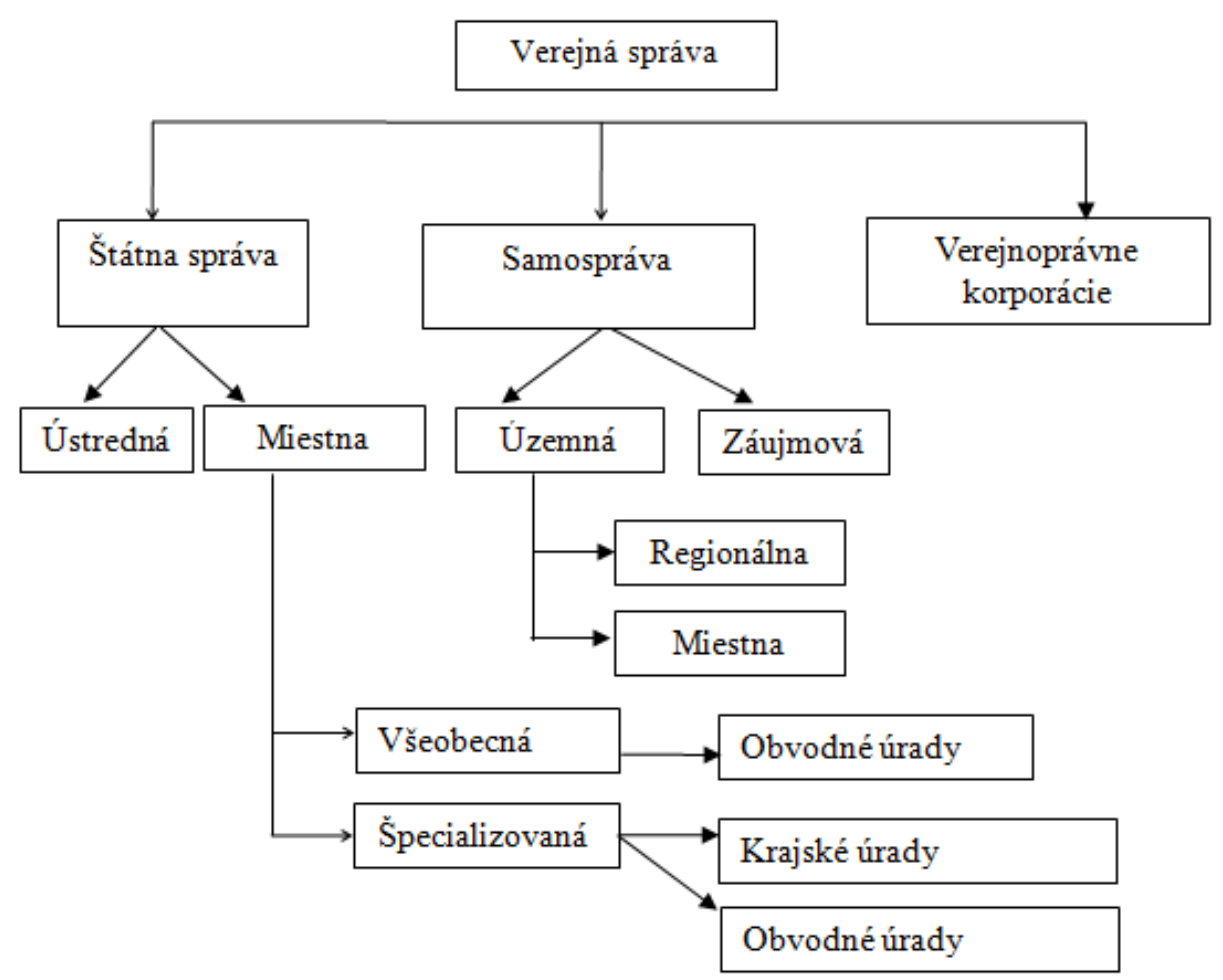

Zdroj: Marišová, E. 2012. Nová štruktúra verejnej správy. Dostupne: http://www.fesrr.uniag.sk/node/397

Pred rokom 2004 bola siet' krajských a okresných úradov pre ministerstvá jednotná v počtoch a existovala i sústava úradov štátnej správy všeobecného charakteru, ktoré boli v pôsobnosti ministerstva vnútra. Napriek zmenám uskutočneným $v$ tejto časti reformy verejnej správy zostala štátna správa nesymetricky usporiadaná, neprehl'adná a prebyrokratizovaná. Preto v súčasnosti vznikla potreba prijat' legislatívne opatrenia smerujúce $\mathrm{k}$ vytvoreniu novej štruktúry miestnych orgánov štátnej správy, ktorej podstatou bude integrácia pôsobností orgánov špecializovanej miestnej štátnej správy do jedného štátneho úradu na miestnej úrovni so všeobecnou vecnou kompetenciou. Dôležitými princípmi pri vytváraní novej štruktúry miestnych orgánov štátnej správy sú najmä zjednodušenie kontaktu občana so štátnou správou, transparentnost' a efektívnost' nakladania s verejnými prostriedkami a účinná kontrola. Týmto účelom zodpovedá zároveň centralizácia podporných činností prierezového a obslužného charakteru, čo predpokladá centralizáciu personálnych činností, správy majetku štátu, ochrany objektov, verejného obstarávania, ako aj financovania (Puček, Ochrana, 2009).

\subsection{Reforma štántej správy pod názvom ESO - Efektívna, Spol’ahlivá a Otvorená štátna správa}

Uznesením vlády SR č. 164 z 27. apríla 2012 bol schválený Program ESO (Efektívna, Spol’ahlivá a Otvorená štátna správa), ktorý pripravuje súčasná vláda. Táto reforma je považovaná za najzásadnejšiu reformu štátnej správy od roku 1989. Podl'a predsedu vlády má priniest' flexibilnejšie fungovanie štátnych úradov ako aj nižší počet štátnych rozpočtových organizácií. Ciel'om predloženého návrhu zákona je vytvorenie právneho základu na vybudovanie novej štruktúry miestnych orgánov štátnej správy integráciou pôsobností špecializovanej miestnej štátnej správy do jedného štátneho úradu, ako to vyplýva z Programového vyhlásenia vlády Slovenskej republiky na obdobie rokov 2012 až 2016 a z programu ESO v dvoch etapách. Prvá etapa je zameraná na zmeny v miestnej štátnej správe, ktorých ciel'om je zrušenie prevažnej väčšiny krajských štruktúr miestnych orgánov štátnej správy. Tento krok už bol realizovaný, k 1.1.2013 došlo k zrušeniu 64 štátnych úradov. Pôsobnost' krajských školských úradov a krajských stavebných úradov prešla na existujúce obvodné úrady v sídle kraja v pôsobnosti Ministerstva obrany SR. Kompetencie zrušených krajských 
úradov životného prostredia; krajských pozemkových úradov; krajských lesných úradov; katastrálnych úradov; krajských úradov pre cestnú dopravu a pozemné komunikácie boli presunuté do príslušného špecializovaného orgánu nižšieho stupňa v pôsobnosti príslušného ústredného orgánu štátnej správy.

Obr. 2: Stav špecializovaných orgánov štátnej správy zriadených na úrovni krajov a obvodov pod gesciou príslušných ministerstiev $k$ 1.1.2013

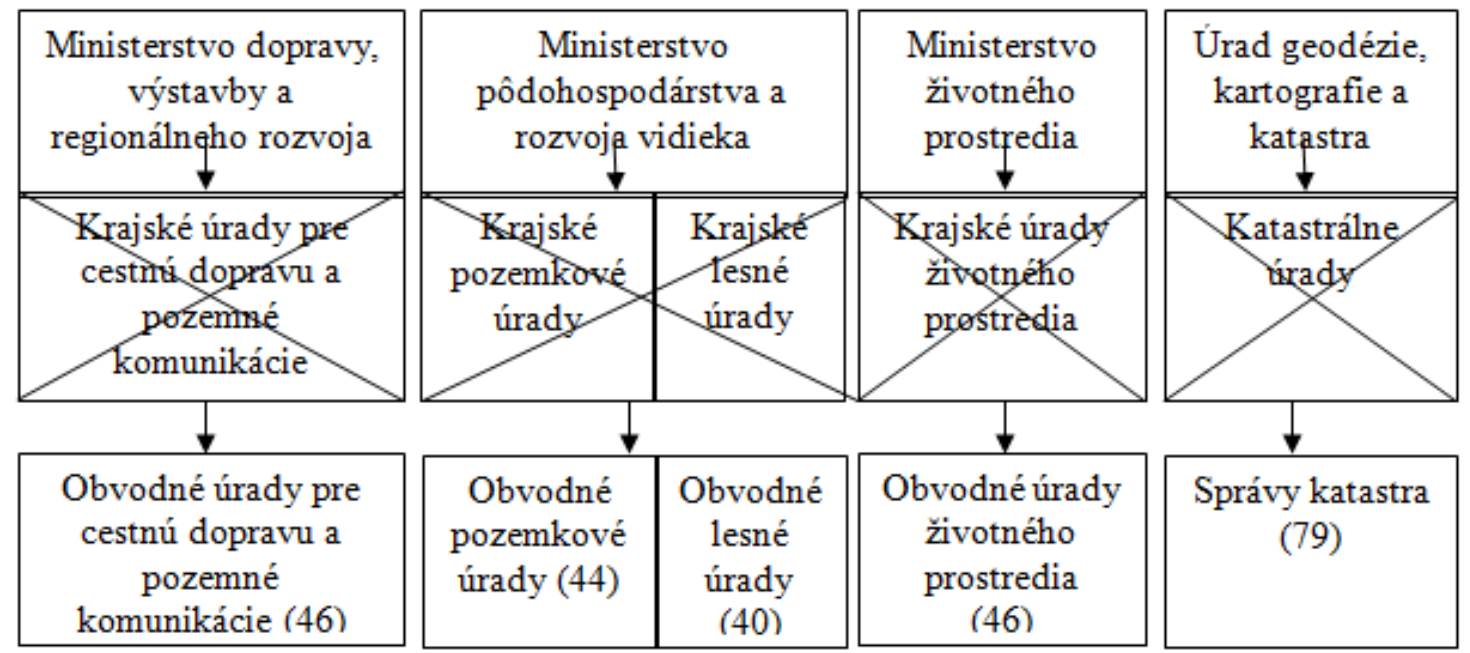

Zdroj: Marišová, E. 2012. Nová štruktúra verejnej správy. Dostupne: http://www.fesrr.uniag.sk/node/397

Obr. 3: Stav špecializovanývh orgánov štátnej správy zriadených na úrovni ústredia a obvodov pod gesciou príslušných ministerstiev $k$ 1.1.2013
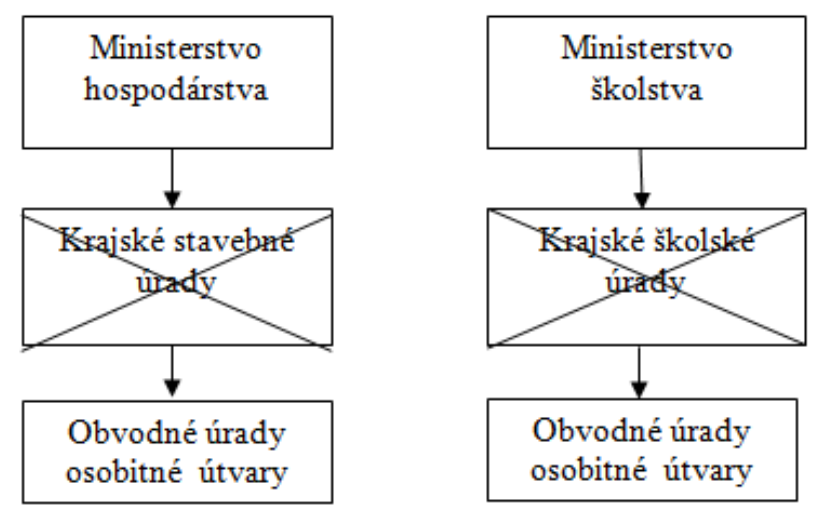

Zdroj: Marišová, E. 2012. Nová štruktúra verejnej správy. Dostupne online: http://www.fesrr.uniag.sk/node/397

Druhá etapa je zameraná na zníženie výdavkov na štátnu správu vytvorením predpokladov pre centralizáciu podporných činností prierezového alebo obslužného charakteru (napr. personalistika, mzdy, správa majetku štátu, ochrana objektov, verejné obstarávanie, rozpočet) a zjednodušenie kontaktu občana so štátnou správou prostredníctvom jedného obslužného miesta. K 1.1.2014 má dôjst' k reduckií 916 rozpočtových organizácií, z ktorých by malo zostat' 58. Hlavným ciel'om tejto druhej etapy procesu integrácie je tiež vytvorenie jednotnej a prehl'adnej štruktúry miestnych orgánov štátnej správy sústredením pôsobností vybraných orgánov špecializovanej miestnej štátnej správy do jedného štátneho úradu na miestnej úrovni. Konkrétne má od 1. októbra 2013 vzniknút' 72 okresných úradov. Nahradia 248 úradov miestnej štátnej správy, z toho $40 \mathrm{~s}$ právnym postavením rozpočtovej organizácie štátu (www.rokovania.sk). 


\section{Záver}

Ciel’om prvej etapy programu ESO, reformy miestnej štátnej správy, je znížit' náklady na výkon činností štátnej správy a realizovat' opatrenia $\mathrm{v}$ oblasti teritoriálnej pôsobnosti, rozmiestnenia a dostupnosti služieb verejnej správy. Splneniu týchto ciel'ov bráni celý rad problémov, ktoré sú brzdou vytvorenia modernej a efektívnej verejnej správy. Patria sem najmä:

- absencia riadiaceho a koordinačného centra,

- nedostatky $v$ organizačnej štruktúre územnej štátnej správy: rozdrobená funkčnost', neprehl'adnost', prebyrokratizovanie, nízka výkonnost' a i.,

- dlhodobá absencia účinnej komunálnej politiky,

- nejednoznačná zodpovednost' za výkon verejných vecí,

- absencia prepojeného systému vzdelávania,

- absencia stabilizácie riadiacich štruktúr a iné.

Preto si myslíme, že reforma miestnej štátnej správy predstavuje významnú, ale len parciálnu kvalitatívnu zmenu v systéme verejnej správy. Napriek tomu, že je dopracovaná do zákonnej normy, pri jej hodnotení sa vynára celý rad problémov. Nazdávame sa, že prvá etapa reformy ESO nie je súčast'ou komplexu kvalitatívnych systémových zmien, že nie je definovaná vízia modernizovanej verejnej správy na Slovensku, že sa nepočítalo s potrebou prehodnotenia kompetencií medzi štátnou správou a samosprávou a že miestna štátna správa nie je personálne pripravená na zvyšovanie účinnosti a efektívnosti. Reforma miestnej štátnej správy by podl’a nášho názoru mala byt' zosúladená a nadväzujúca na riešenie problémov týkajúcich sa fragmentovanej sídelnej štruktúry. Podl’a nás je potrebné riešit' predovšetkým situáciu v samospráve, a až potom následne nájst' najvhodnejší systém organizačnej štruktúry v štátnej správe. Oddelené riešenia obidvoch podsystémov štátnej správy vedú k neefektívnym a neprehl'adným.

\section{Literatura}

[1] COMBES, D.,VERHIJEN, T. Reforma verejnej správy. Porovnanie skúseností Východu a Západu. Bratislava: NISPAcee, 1997, ISBN 80-967616-5.

[2] HAMALOVÁ, M. Teória, riadenie a organizácia verejnej správy. 2. čast: Organizácia verejnej správy. 1. vyd. Bratislava: Merkury, 2008. ISBN 978-80-89143-63-4.

[3] http://www.rokovania.sk/File.aspx/ViewDocumentHtml/Mater-Dokum 1471111?prefixFile=m

[4] NIŽŇANSKÝ, V. Decentralizácia na Slovensku. Bratislava: Úrad vlády SR, 2005, ISBN 80969447-1-1.

[5] OCHRANA, F., PUČEK, M. Efektívni zaváděni a ř́zeni změn ve veřejné správě: Smart administration. 1. Vydanie. Praha: Wolters Kluwer ČR, 2011. 246 s. ISBN 9788073-576677

[6] PUČEK, M., OCHRANA, F. a kol. Chytrá veřejná správa. Kohezni politika. Ministerstvo pro místní rozvoj, Národní orgán pro koodinaci, 2009, ISBN 978-80-86616-27-4.

[7] Stratégia reformy verejnej správy vSlovenskej republike. 1999. Dostupné z: $<$ https://www.fphil.uniba.sk/fileadmin/user_upload/editors/kpol/publikacie/lastic/ucebnytext_us/s trategia_071999.pdf>

[8] ŽÁRSKA-A, E., ČERNENĚNKO, T., KOZOVSKÝ, D. Verejná správa I. Vydavatel'stvo EKONÓM, 2010. ISBN 978-80-225-3113-9. 